\title{
Effect of Surface Treatment of Adhesive Bonded Sheet of Aluminium Alloy EN AW 2024 T3 on Adhesive Bond Strength Created by Means of Structural Two-Component Adhesive
}

\section{Miroslav Müller}

Faculty of Engineering, Czech University of Life Sciences Prague. Kamýcká 129, Czech Republic. E-mail: muller@tf.czu.cz.

\begin{abstract}
When constructing traffic means, agricultural machines etc. it is necessary to create a bond, namely from thin semi-products, i.e. sheets of metal. Namely light and strong materials such as e.g. aluminium alloys EN AW 2024 $\mathrm{T3}(\mathrm{AlCu} 4 \mathrm{Mgl})$ are used in the constructions. A research namely on the adhesive bonded surface treatment is necessary at a rise of the quality adhesive bond. The aim of the research is an evaluation of the adhesive bonded surface treatment of the aluminium alloy EN AW 2024 T3 (AlCu4Mg1) by means of mechanical tests and a surface analysis by means of SEM. A cyclic degradation loading of the adhesive bond after exposing the adhesive bonds to increased and decreased temperatures, i.e. in the interval -40 to $70{ }^{\circ} \mathrm{C}$ in a programmable climatic chamber MKF240 and connected adhesive bonded surface treatments were evaluated within the research. The adhesive bonded surface treatment was of the positive influence on the strength and the elongation of the adhesive bond and it increased the resistance to the cyclic acting of the degradation environment at the same time.
\end{abstract}

Keywords: adhesive bond strength, chemical treatment, mechanical treatment, SEM, surface roughness

\section{Acknowledgement}

Supported by Internal grant agency of Faculty of Engineering, Czech University of Life Sciences Prague (2017: 31140/1312/313115).

\section{References}

[1] MICHNA, S., NÁPRSTKOVÁ, N., KLIMECKA-TATAR, D. (2015). Research the causes of surface stains after eloxal coating for the profile from the AlMgSi alloy using substrucrural analysis. In: Manufacturing Technology, Vol. 15, pp. 620-624.

[2] MICHNA, S., MAJRICH, P. (2012). Possible ways of obtaining an aluminium allay by non-traditional waste processing of aluminium beverage containers. In: Manufacturing Technology, Vol. 12, pp. 169-174.

[3] HRICOVA, J., NÁPRSTKOVÁ, N. (2015). Surface roughness optimization in milling aluminium alloy by using the Taguchis design of experiment. In: Manufacturing Technology, Vol. 15, pp. 541-546.

[4] PEREIRA, J.M., FERREIRA, F.V., ANTUNES, P.J., BÁRTOLO A.M. (2010). Analysis of manufacturing parameters on the shear strength of aluminium adhesive single-lap joints. In: Journal of Materials Processing Technology. Vol. 210, pp. 610-617.

[5] MÜLLER, M. (2015). Research on surface treatment of alloy AlCu4Mg adhesive bonded with structural singlecomponent epoxy adhesives. In: Manufacturing Technology, Vol. 15, pp. 629-633.

[6] MÜLLER, M. (2017). Effects of aluminium microparticles and surface treatment of AlCu4Mg on mechanical properties of adhesive bond strength. In: Manufacturing Technology, Vol. 17, pp. 66-71.

[7] BNESAJJAD, S., LANDROCK, A.H. (2014). Adhesives Technology Handbook, 3rd edition, William Andrew, $432 \mathrm{p}$.

[8] MESSLER, R. W. (2004). Joining of materials and structures from pragmatic process to enabling technology. Burlington: Elsevier, $816 \mathrm{pp}$.

[9] RUGGIERO, A., VALÁŠEK, P., MEROLA, M. (2015). Friction and wear behaviors of Al/Epoxy Composites during Reciprocating Sliding tests. In: Manufacturing technology, Vol. 15, pp. 684-689.

[10] BOCKENHEIMER, C., VALESKE, B., POSSART, W. (2002). Network structure in epoxy aluminium bonds after mechanical treatment. In: International Journal of Adhesion \& Adhesives, Vol. 22, pp. 349-356.

[11] RUDAWSKA, A. (2014). Selected aspects of the effect of mechanical treatment on surface roughness and adhesive joint strength of steel sheets. In: International Journal of Adhesion and Adhesives, Vol. 50, pp. 235-243.

[12] HARRIS, A.F., BEEVERS, A. (1999). The efects of grit-blasting on surface properties for adhesion. In: International Journal of Adhesion \& Adhesives, Vol. 19, pp. 445-452. 
[13] ELBINGA, F., ANAGREHB, N., DORNA, L., ULMANNA, E. (1999). Dry ice blastingas pretreatment of aluminum surfaces to improve the adhesive strength of aluminium bonding joints. In: International Journal of Adhesion \& Adhesives, Vol. 23 pp. 69-79.

[14] LUNDER, O., LAPIQUE, B., JOHNSEN, K., NISANCIOGLU K. (2004). Effect of pre-treatment on the durability of epoxy-bonded AA6060 aluminium joints. In: International Journal of Adhesion \& Adhesives, Vol. 24, pp. 107117.

[15] BJORGUM, A., LAPIQUE, F., WALMSLEY, J., REDFORD K. (2003). Anodising as pre-treatment for structural bonding. In: International Journal of Adhesion \& Adhesives, Vol. 23, pp. 401-412.

[16] MÜLLER, M., HERÁK, D., VALÁŠEK, P. (2013). Degradation limits of bonding technology depending on destinations Europe, Indonesia. In: Tehnicki Vjesnik-Technical Gazette, Vol. 20, pp. 571-575.

[17] MULLER, M., VALÁŠEK, P. (2012). Degradation medium of agrokomplex - adhesive bonded joints interaction. In: Research in Agricultural Engineering, Vol. 58, pp. 83-91.

[18] NING SU, R.I., MACKIE W.J.H. (1992). The effects of ageing and environmental on the fatugue life of adhesive joints. In: International Journal of Adhesion \& Adhesives, Vol. 12, pp. 85 - 93.

[19] CROCOMBE, A.D. (1997). Durability modelling concepts and tools for the cohesive environmental degradation of bonded structure. In: International Journal of Adhesion \& Adhesives, Vol. 17, pp. 229 - 238.

[20] MÜLLER, M., VALÁŠEK, P., RUDAWSKA, A. (2017). Mechanical properties of adhesive bonds reinforced with biological fabric. In: Journal of adhesion science and technology, Vol. 31, pp. 1859-1871.

[21] HAHID, M., HASHIM, S. A. (2002). Effect of surface roughness on the strength of cleavage joints. In: International Journal of Adhesion \& Adhesives, Vol. 22, pp. $235-244$.

[22] POORNA CHANDER, K., VASHISTA, M., SABIRUDDIN, K., PAUL, S., BANDYOPADHYAY, P.P. (2009). Effects of grit blasting on surface properties of steel substrates. In: Materials \& Design, Vol. 30, pp. 2895 - 2902.

[23] WANG, Y., YANG, Z. (2009). Coupled finite element and meshfree analysis of erosive wear. In: Tribology International, Vol. 42, pp. $373-377$.

[24] HARRIS, A. F., BEEVERS, A. (1999). The effects of grit-blasting on surface properties for adhesion. In: International Journal of Adhesion \& Adhesives, Vol. 19, pp. 445 - 452.

[25] RUDAWSKA, A., DANCZAK, I., MULLER, M., VALAŠEK, P. (2016). The effect of sandblasting on surface properties for adhesion. In: International Journal of Adhesion and Adhesives. Vol. 70, pp. 176-190.

[26] TAMAI, Y., ARATANIC, K., (1972). Experimental study of the relation between contact angle and surface roughness. In: The Journal of Physical Chemistry. Vol. 22, pp. 3267-3271.

[27] PEREIRA, J.M., FERREIRA, F.V., ANTUNES, P.J., BÁRTOLO A.M. (2010). Analysis of manufacturing parameters on the shear strength of aluminium adhesive single-lap joints. In: Journal of Materials Processing Technology. Vol. 210, pp. 610-617.

[28] CIDLINA, J., MÜLLER, M. (2015). Influence of adhesive bonded surface treatment of alloy $\mathrm{AlCu} 4 \mathrm{Mg}$ and increased environmental temperature on adhesive bond strength. In: Manufacturing Technology, Vol. 15, pp. 520526.

[29] RUSHFORTH, M.W., BOWEN, P., MCALPINE, E., ZHOU, X., THOMPSON, G.E. (2004). The pretreatment and moisture on the fatigue performance of adhesively bonded aluminum. In: Journal of materials processing technology, Vol. 153-154, pp. 359-365.

[30] DOYLE, G., PETJROCK, R. A. (2009). Environmental effects on the ageing of epoxy adhesive joints. In: International Journal of Adhesion \& Adhesives, Vol. 29, pp. 77-90.

[31] MESSLER, R., W. (2004). Joining of materials and structures from pragmatic process to enabling technology. Burlington: Elsevier, 816 pp. 